\title{
DESIGN AND SIMULATION OF AN AIR CONDITIONING PROJECT IN A HOSPITAL BASED ON COMPUTATIONAL FLUID DYNAMICS
}

\author{
DING X.R. ${ }^{1}$, GUO Y.Y. ${ }^{2}$, CHEN Y.Y. ${ }^{3}$
}

\begin{abstract}
This study aims to design a novel air cleaning facility which conforms to the current situation in China, and moreover can satisfy our demand on air purification under the condition of poor air quality, as well as discuss the development means of a prototype product. Air conditions in the operating room of a hospital were measured as the research subject of this study. First, a suitable turbulence model and boundary conditions were selected and computational fluid dynamics (CFD) software was used to simulate indoor air distribution. The analysis and comparison of the simulation results suggested that increasing the area of air supply outlets and the number of return air inlets would not only increase the area of unidirectional flow region in main flow region, but also avoid an indoor vortex and turbulivity of the operating area. Based on the summary of heat and humidity management methods, the system operation mode and relevant parameter technologies as well as the characteristics of the thermal-humidity load of the operating room were analyzed and compiled. According to the load value and parameters of indoor design obtained after our calculations, the airflow distribution of purifying the air-conditioning system in a clean operating room was designed and checked. The research results suggested that the application of a secondary return air system in the summer could reduce energy consumption and be consistent with the concept of primary humidity control. This study analyzed the feasibility and energy conservation properties of cleaning air-conditioning technology in operating rooms, proposed some solutions to the problem, and performed a feasible simulation, which provides a reference for practical engineering.
\end{abstract}

Keywords: Computational fluid dynamics technology; clean operating room; numerical simulation; turbulence model; engineering design

\footnotetext{
${ }^{1}$ ME, The First Affiliated Hospital of Wenzhou, Wenzhou, Zhejiang, 325000, China, e-mail: dingxr1989@126.com ${ }^{2}$ ME, The First Affiliated Hospital of Wenzhou, Wenzhou, Zhejiang, 325000, China, e-mail: imguoyaya@hotmail.com ${ }^{3}$ ME, The First Affiliated Hospital of Wenzhou, Wenzhou, Zhejiang, 325000, China, e-mail: chyunyu23@163.com X. R. Ding and Y. Y. Guo are co-first authors.
} 


\section{INTRODUCTION}

With the rapid development of the Chinese economy and the constant breakthroughs of various scientific technologies in China and abroad, people are demanding more from production and life [1]. Construction, as support of most human activities, is set with different design conditions and service conditions according to its types and uses. Because of the strict requirements of some special industrial fields and production techniques in an indoor environment, the use of sterile rooms such as operating theatres and instrument calibration workshops has been applied more extensively [2]. Sterile rooms have stricter requirements on the temperature, humidity, and purity of indoor air compared to ordinary buildings [3]. According to statistics, the energy consumption of air-conditioning systems in sterile rooms is more than 50 times that of ordinary building of the same volume [4].

Gao Jun et al. [5] simulated a temperature field in a large space which adopted clean airconditioning technology using computational fluid dynamics (CFD) technology, then made an intuitive analysis on the distribution characteristics of indoor temperature, and collected the characteristics of multi-jet motion. Man Xiaoxin et al. [6] performed a three-dimensional numerical simulation on the airflow distribution of clean air conditioning in a large cleaning workshop using the $\mathrm{K}-\varepsilon$ two-equation turbulence model and analyzed the properties such as concentration field, speed field, and energy savings. In recent years, the advantages and disadvantages of different airflow forms in a large space based on CFD technology have been studied more extensively [7]. Lai Hejing $[8,9]$ made summer and winter simulations in a large space using Fluent software and then analyzed the energy consumption of different airflow distribution forms. Dong Xiufang et al. [10] simulated airflow distribution, concentration field, and temperature field of clean air conditioning in a large cleaning workshop and analyzed the applicability of clean air conditioning in a clean workshop.

In this study, a clean operating room was used as the research subject and clean air conditioning technology was adopted. The cooling load of clean air conditioning in summer was calculated through two methods; the practical clean air conditioning cooling load calculation method, and the simulation calculation based on energy $[11,12]$. The calculated results were analyzed and compared. Airflow distribution was simulated using the CFD software Airpak3.0, and the simulation results were analyzed as well. This study analyzed the feasibility and energy saving property of clean air conditioning technology in clean operating rooms and made simulations regarding the feasibility of 
relevant solutions for potential problems which may occur in practical operation of this project. This work provides a reference for practical engineering.

\section{THE MODE OF AIR CONDITIONING CLEANING： ENGINEERING IN HOSPITALS AND CFD TECHNOLOGY}

\subsection{SYSTEM MODE OF AIR CONDITIONING CLEANING: ENGINEERING IN HOSPITALS}

Differing from ordinary cleaning workshops, air conditioning systems in clean operating rooms highlight the characteristics of biological cleaning and pay more attention to key positions of protection and comprehensive control of bacteria; the goal is setting up a set of sterile environment security systems through implementing whole-process control [13]. The air conditioning system in a clean operating room is usually composed of an air supply ceiling, air treatment equipment, an air pipe, and an air adjustment and control system. A single-machine clean air conditioning system usually adopts an air conditioning unit which has functional sections of fresh air filtration, return air mixing, heat and moisture treatment, and an air supplier and air supply section filtration. Details of the system are shown in Fig. 1.

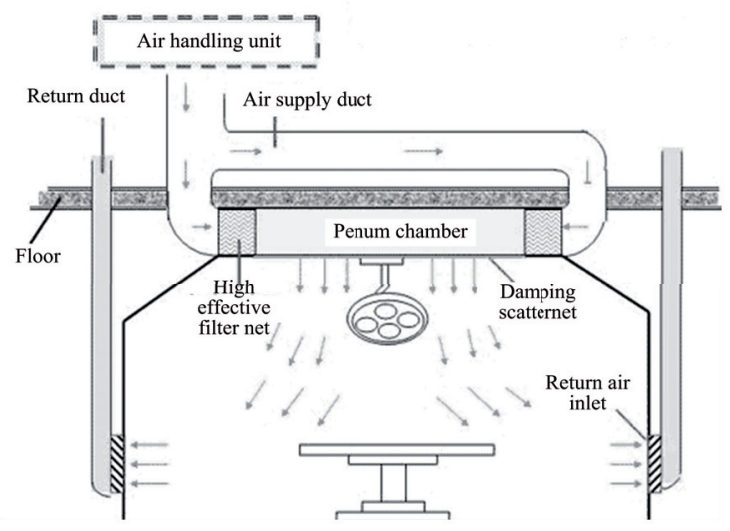

Fig. 1. Schematic diagram of a single-machine system in operating room 
The multi-machine system is frequently used in the design of clean operating rooms. Compared to the single-machine system, the multi-machine system is composed of multiple cycle air conditioning units. The multi-machine systems used in operating rooms are composed of dispersed air conditioning units and fresh air handling units; the system is capable of separating clean air conditions in every operating room and maintaining its positive pressure as well as closely integrating multiple operating rooms. Unlike the traditional air conditioning system, the multimachine system can avoid the instability induced by air volume and pressure when all operating rooms are in use at the same time. When only a fraction of the operating rooms is used, the multimachine system can ensure the normal operation of those occupied rooms as well as the pressure and air supply of the vacant ones. Details of the multi-machine system are shown in Fig. 2.

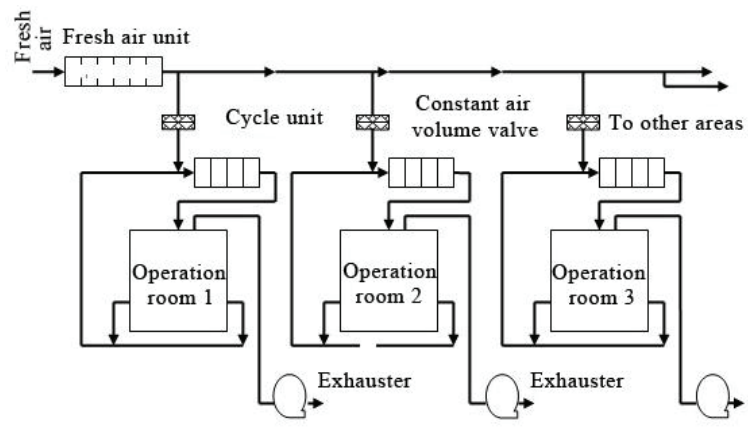

Fig. 2. Schematic diagram of a multi-machine system in operating room

\subsection{CFD TECHNOLOGY}

With the rapid development of computer technology and the application of experimental simulations of high-speed computers, computer simulation has been applied extensively. CFD as a science mainly takes aim at fluid mechanics and is based on computer technology. CFD is a product integrating modern fluid mechanics, numerical mathematics, and computer [14]. Quality, momentum, and the energy conservation law are the theoretical basis of a CFD virtual simulation on a computer [15]. Compared to traditional technology, CFD technology is preferred due to low cost, high speed, short cycles, and complete data. Moreover, it can test the state of measured data 
during operation and is free from the limitation of experimental models and complex space, which avoids the waste of manpower, financial resources, and material resources.

CFD mainly involves three steps: the establishment of a mathematical physical model, the numerical algorithm solution, and result visualization. Fluent software - the mainstream software of CFD currently, includes a pre-processing module, an analysis and calculation module, and a postprocessing module [16]. Compared to the traditional CFD calculation method, Fluent software stands out through good stability, a wide application scope, and high precision. CFD technology can therefore be applied for simulations and predictions of indoor air distribution, and the evaluation and selection of conceptual design schemes [17].

\section{MODELING AND SIMULATION OF AIRFLOW IN CLEAN AIR CONDITIONING ROOMS IN HOSPITALS}

\subsection{TURBULENCE SIMULATION METHOD}

Airflow in an operating room is usually in a turbulence state. Though turbulent flow is a kind of nonlinear complex flow, simulation methods for turbulent flow have been found [18]. The nonsteady continuity equation and the Navier-Stokes equation are both applicable to the instantaneous movement of incompressible newton-type fluid turbulent flow. In coordinate, the general form of the control equation for turbulent flow is as follows:

$$
\frac{\partial(\rho \phi)}{\partial t}+\operatorname{div}(\rho U \phi)=\operatorname{div}(\Gamma \operatorname{grad} \phi)+S
$$

where:

$\phi$ stands for the universal variable, $\Gamma$ stands for the generalized diffusion coefficient, and $\mathrm{S}$ stands for the generalized source item.

Numerical simulation methods for turbulence include direct simulation and non-direct simulation. The solution of Eq. (3.1) is a direct simulation method. The non-direct simulation method refers to a 
certain degree of both approximate and simplified treatments on the pulsation property of turbulent flow (instead of direct calculation). Non-direct simulation methods can be typed into a large eddy simulation, the statistical average method, and the Reynolds average method [19].

\subsection{TURBULENCE MODEL}

The key of solving turbulent motion lies in setting up an extensively applicable turbulence model. Due to the restriction of calculation conditions, this study adopted the eddy viscosity model which involves little computational work. According to the number of additional differential equations, eddy viscosity models can be divided into a zero-equation model, a one-equation model, and a twoequation model. The zero-equation model integrates turbulence viscosity and the time-average value using algebraic relational expression. The zero-equation model, which is not suitable for simulating separated turbulent flow and free shear flow, is defined by little time consumption and rapid calculation and convergence speed; therefore, it is suitable for general direct numerical simulations on a computer. Data obtained in numerical simulations using the MIT zero-equation model have high consistency and precision [20,21].

The one-equation model is established based on the zero equation and the characteristic quantity equation, which avoids the influence of convection and diffusion ignored in the zero-equation model. Turbulence characteristic quantity can be written as the following form using the turbulence energy K equation:

$$
\rho \frac{\partial k}{\partial t}+\rho u_{i} \frac{\partial k}{\partial x_{i}}=\frac{\partial}{\partial x_{j}}\left[\left(\mu+\frac{\mu_{t}}{\sigma_{k}}\right) \frac{\partial k}{\partial x_{j}}\right]+\left(\frac{\partial u_{i}}{\partial x_{j}}+\frac{\partial u_{j}}{\partial x_{i}}\right) \frac{\partial u_{i}}{\partial x_{j}}-\rho C_{D} \frac{k^{3 / 2}}{l}
$$

where:

$$
\rho \frac{\partial k}{\partial t} \text { - an unsteady term, } \rho u_{i} \frac{\partial k}{\partial x_{i}} \text { - a convective term, } \frac{\partial}{\partial x_{j}}\left[\left(\mu+\frac{\mu_{t}}{\sigma_{k}}\right) \frac{\partial k}{\partial x_{j}}\right] \text { - a diffusion term, }
$$
$\left(\frac{\partial u_{i}}{\partial x_{j}}+\frac{\partial u_{j}}{\partial x_{i}}\right) \frac{\partial u_{i}}{\partial x_{j}}$ - a generation term, $\rho C_{D} \frac{k^{3 / 2}}{l}-$ a dissipation term, $l$ - the length scale of turbulent fluctuation, $\sigma_{k}$ - the Prandtl number of pulsating kinetic energy, $C_{D}$ - an empirical constant 
As $l$ is difficult to confirm, the one-equation model will be severely restrained [22]. A standard K$\mathcal{E}$ equation is an extensively applied two-equation model which is formed by introducing a dissipation rate based on one equation, turbulent viscosity $\mu_{t}=\rho C_{\mu} \frac{k^{2}}{\varepsilon}$. The continuity equation is as follows:

$$
\frac{\partial \rho}{\partial t}+\frac{\partial\left(\rho \bar{u}_{i}\right)}{\partial x_{i}}=0
$$

The momentum equation is as follows:

$$
\frac{\partial\left(\rho \bar{u}_{i}\right)}{\partial t}+\frac{\partial\left(\rho \bar{u}_{i} \bar{u}_{j}\right)}{\partial x_{j}}=-\frac{\partial \bar{p}}{\partial x_{i}}+\frac{\partial}{\partial x_{j}}\left(\eta \frac{\partial \bar{u}_{i}}{\partial x_{j}}-\rho \bar{u}_{i}^{\prime} \bar{u}_{j}^{\prime}\right)
$$

The energy equation is as follows:

$$
\frac{\partial(\rho h)}{\partial t}+\frac{\partial(\rho u h)}{\partial x}+\frac{\partial(\rho v h)}{\partial y}+\frac{\partial(\rho w h)}{\partial z}=-p \operatorname{div} U+\operatorname{div}(\lambda \operatorname{grad} T)+\phi+S_{h}
$$

The turbulent kinetic energy equation is as follows:

$$
\rho \frac{\partial k}{\partial t}+\rho u_{j} \frac{\partial k}{\partial x_{j}}=\frac{\partial}{\partial x_{j}}\left[\left(\eta+\frac{\eta_{t}}{\sigma_{k}}\right) \frac{\partial k}{x_{j}}\right]+\eta_{t} \frac{\partial u_{i}}{\partial x_{j}}\left(\frac{\partial u_{i}}{\partial x_{j}}+\frac{\partial u_{j}}{\partial x_{i}}\right)-\rho \varepsilon
$$

The equation of turbulence energy dissipation rate is as follows:

$$
\rho \frac{\partial \varepsilon}{\partial t}+\rho u_{k} \frac{\partial \varepsilon}{\partial x_{k}}=\frac{\partial}{\partial x_{k}}\left[\left(\eta+\frac{\eta_{t}}{\sigma_{\varepsilon}}\right) \frac{\partial k}{x_{k}}\right]+\frac{c_{1} \varepsilon}{k} \eta_{t} \frac{\partial u_{i}}{\partial x_{j}}\left(\frac{\partial u_{i}}{\partial x_{j}}+\frac{\partial u_{j}}{\partial x_{i}}\right)-c_{2} \rho \frac{\varepsilon^{2}}{k}
$$


Though the standard K-E model is an improvement when compared to the other two models, distortion will also occur when there are special conditions present. However, it is incapable of accurately reflecting the historic effect and anisotropy of Reynolds stress as well as the equation distribution influence [23].

\section{Simulation CALCULATION OF NUMERICAL VALUE OF CLEAN AIR CONDITIONING PROJECT BASED ON CFD}

The wind speed of operating areas in clean operating rooms under different ventilation rates was calculated according to the established models. Fluent software was used to post-process the wind speed of the operating area, and MATLAB software was used to perform three-dimensional visualization processing on the wind speed of the spots tested. The air supply outlet area of model A and B was $4.68 \mathrm{~m}^{2}$ and $2.4 \mathrm{~m}^{2}$ respectively, and the supply air temperature was $297.15 \mathrm{~K}$.

Table 1 . Air supply velocity under different ventilation rates $(\mathrm{m} / \mathrm{s})$

\begin{tabular}{|c|c|c|c|c|c|c|c|c|}
\hline & $\begin{array}{c}15 \\
\text { times } / \mathrm{h}\end{array}$ & $\begin{array}{c}20 \text { times } \\
/ \mathrm{h}\end{array}$ & $\begin{array}{c}25 \\
\text { times } / \mathrm{h}\end{array}$ & $\begin{array}{c}30 \\
\text { times } / \mathrm{h}\end{array}$ & $\begin{array}{c}35 \text { times } \\
/ \mathrm{h}\end{array}$ & $\begin{array}{c}40 \text { times } \\
/ \mathrm{h}\end{array}$ & $\begin{array}{c}45 \text { times } \\
\mathrm{h}\end{array}$ & $\begin{array}{c}50 \text { times } \\
/ \mathrm{h}\end{array}$ \\
\hline Model A & 0.088 & 0.118 & 0.145 & 0.178 & 0.206 & 0.236 & 0.266 & 0.298 \\
\hline Model B & 0.178 & 0.226 & 0.285 & 0.336 & 0.392 & 0.448 & 0.503 & 0.566 \\
\hline
\end{tabular}

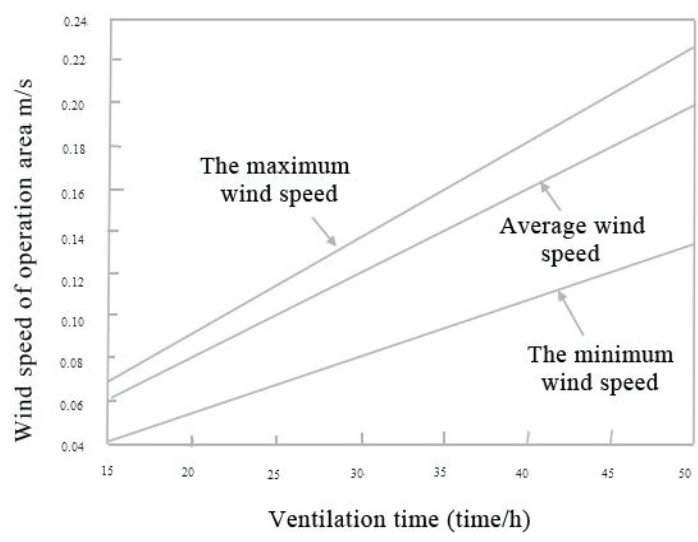

Fig. 3. The relationship between wind speed of the operating areas and ventilation times in model A 


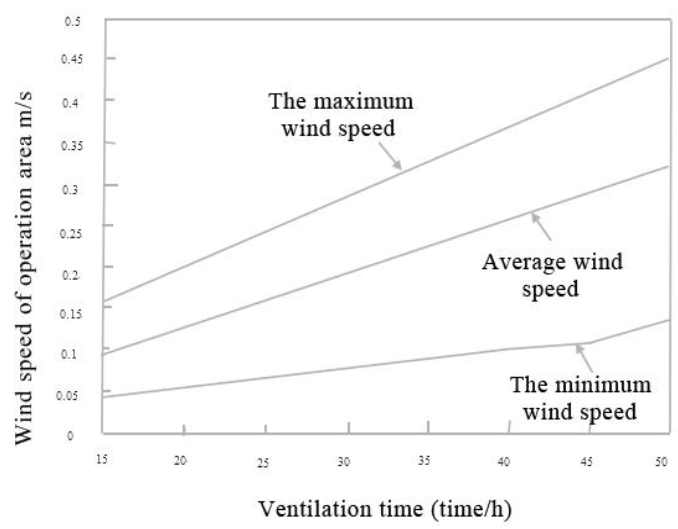

Fig. 4. The relationship between wind speed of the operating areas and ventilation times in model B

The air supply areas of the two models are different. Simulation results suggested that the wind speed of the velocity field tended to decrease significantly with the increase of the size of the air supply area. Figures 3 and 4 demonstrate that the maximum and average wind speeds of model A were all lower than those of model B. As the area of the air supply outlet of model A was 1.95 times that of model B, the air supply speed of model A was much lower than that of model B under the same ventilation times. However, under the same ventilation times, the minimum wind speeds of models A and B were the same; the difference between model A and model B was significant only when the ventilation rate was 45 times/h.

The evenness of the velocity field is of vital importance to clean operating rooms. The uneven distribution of the velocity field will enhance the pulsatility of speed and confuse mass points in the flow field. The turbulence degree can suggest the concentration degree or the dispersion degree of different velocity fields. The turbulence degree can be described using the following equation:

$$
\beta=\frac{\sqrt{\frac{\sum\left(v_{i}-\bar{v}\right)^{2}}{n-1}}}{\bar{v}}
$$

where: 
$\beta$ - turbulence degree, ${ }^{v_{i}}$ - speed of testing spot, $\bar{v}$ - average wind speed of operating area, $\mathrm{n}$ - number of testing spots

There were 121 testing spots in total, counting all clean operating rooms in hospitals. The turbulence degree was calculated according to equation (8). The calculation results of turbulence degree $\beta$ of clean operating room models under different ventilation times are shown in Table 2.

Table 2 Turbulence degree $\beta$ of the operation areas under different ventilation times

\begin{tabular}{|c|c|c|c|c|c|c|c|c|}
\hline & $\begin{array}{c}15 \\
\text { times/h }\end{array}$ & $\begin{array}{c}20 \\
\text { times/h }\end{array}$ & $\begin{array}{c}25 \text { times } \\
/ \mathrm{h}\end{array}$ & $\begin{array}{c}30 \\
\text { times } / \mathrm{h}\end{array}$ & $\begin{array}{c}35 \\
\text { times/h }\end{array}$ & $\begin{array}{c}40 \\
\text { times } / \mathrm{h}\end{array}$ & $\begin{array}{c}45 \\
\text { times } / \mathrm{h}\end{array}$ & $\begin{array}{c}50 \text { times } \\
/ \mathrm{h}\end{array}$ \\
\hline Model A & 0.1103 & 0.1106 & 0.1102 & 0.1103 & 0.1104 & 0.1136 & 0.1135 & 0.1136 \\
\hline Model B & 0.2555 & 0.2520 & 0.2512 & 0.2513 & 0.2578 & 0.2628 & 0.2735 & 0.2566 \\
\hline
\end{tabular}

Fig. 5 was drawn adapting turbulence degree $\beta$ and ventilation times of table 2 as the vertical and horizontal coordinates, respectively. The figure demonstrates that the turbulence degree of the operating area of model A was much lower than that of model B; the turbulence degree of the operating area of model B had slight fluctuations; the airflow distribution form of model A was eligible $(\beta \leq 0.02)$.

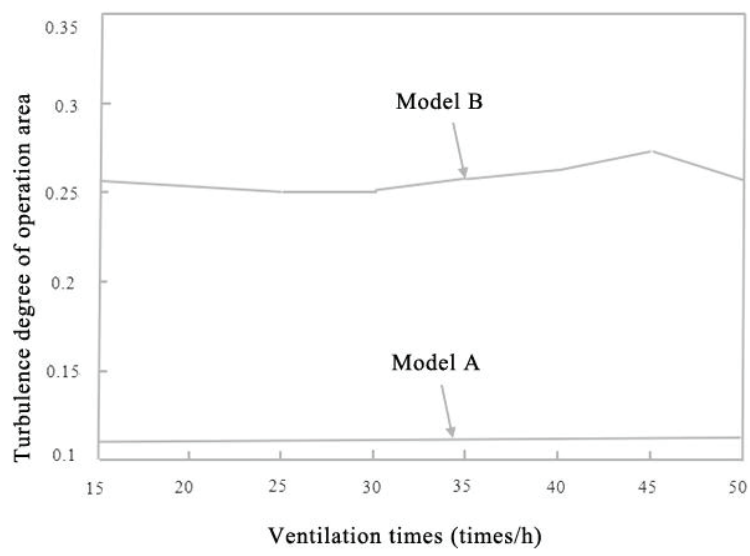

Fig. 5 The relationship between wind speed of the operating areas of model A and B and ventilation times 


\section{CAlCulation OF LOAD OF CLEAN AIR CONDITIONING PROJECT IN A HOSPITAL}

\subsection{COOLING LOAD OF CLEAN AIR CONDITIONING PROJECT IN A HOSPITAL}

$$
q_{c l}=q_{1 w}+q_{1 n}+q_{x}+q_{d}+q_{f}
$$

where:

$q_{c l}$ - the cooling load of air conditioning, $q_{1 w}$ - the cooling load from heat of the building envelope,

$q_{1 n}$ - the cooling load induced by heat generation by an internal heat source, $q_{x}$ - the cooling load induced by outdoor fresh wind or infiltration air, $q_{d}$ - the cooling load induced by convection heat transfer, ${ }^{q}$ - the cooling load induced by radiant heat transfer

The calculation formula of the heat-to-humidity ratio of operating rooms in summer is as follows:

$$
\varepsilon=q_{c l} / W
$$

\subsection{THERMAL LOAD OF CLEAN AIR CONDITIONING PROJECT IN A HOSPITAL}

The thermal load of an operating room in a hospital is mainly composed of heat consumption of the building envelope. The calculation formula of heat consumption is as follows:

$$
q_{H L}=\alpha K F\left(T_{n}-T_{W}\right)
$$

where: 
$q_{H L}$ - the basic heat consumption of the internal building envelope, $\alpha-$ the temperature difference correction factor of the internal building envelope.

The calculation formula of the heat-to-humidity ratio of operating rooms in winter is as follows:

$$
\varepsilon_{d}=q_{H L} / W
$$

\subsection{ANALYSIS OF ENERGY CONSUMPTION PROCESSING OF THE SECONDARY RETURN AIR SYSTEM}

Air conditioning in clean operating rooms is a kind of constant temperature and humidity technical air conditioning which adopts a primary return air system. The above calculation suggests that the system had the problem of counteracting of cold and heat, which can incur large amounts of waste. To conserve heat and cold quantities, a mixed secondary return air system was used to replace the reheater.

It can be seen from the above formulas and detailed parameters of operating rooms in summer that a secondary return air system could save more low temperature quantity than the primary return air system. The amount saved by the secondary return air system was the same as the high temperature quantity saved by the primary return air system; the air volume processed by surface air cooler reduced. It can be concluded that the secondary return air system could save a higher amount of cold air. In winter, however, the heating and humidification capacities of the primary and secondary return air systems were nearly the same.

\section{CONCLUSION}

This study designed and simulated a clean air conditioning project based on CFD technology and compared the data obtained after design and simulation. We eventually came to the conclusion that an increase of the air supply area and return air inlets can increase the area of unidirectional flow regions of the main flow regions, and avoid indoor vortexes and turbulivity in the operating area. The application of a secondary air return system in summers can reduce 
energy consumption and conform to the concept of primary humidity control. The scheme of the clean air conditioning project proposed in this study is of high significance to the practical design of air conditioning systems for clean operating rooms, and it also provides a reference for the design of the operating rooms themselves.

\section{REFERENCES}

1. Z. Ren, W. Song, X. Peng, et al. "The Characteristics of Science and Technology Policy Research from the Perspective of the Characteristics of Science and Technology Activity", Journal of Service Science \& Management, 08(3): 365-371, 2015.

2. E. Zimmermann, S. Derrough, D. Locatelli, et al. "Results of potential exposure assessments during the maintenance and cleanout of deposition equipment", Journal of Nanoparticle Research, 14(10): 1-17, 2012.

3. P. Pérez-López, S. González-García, C. Allewaert, et al. "Environmental evaluation of eicosapentaenoic acid production by Phaeodactylum tricornutum", Science of the Total Environment, 466-467C (1): 991-1002, 2014.

4. J. J. Carter, B. C. Cochran, J. D. Reifschneider. Saving energy in lab exhaust systems. Ashrae Journal, 53(6): 26-36, 2011.

5. J. Gao, X. D. Li, F. S. Gao. "Coincidence and entrainment of air jets of the stratifiedair conditioning in large spaces", Journal of Harbin Institute of Technology, 132(2): 145-155, 2004.

6. X. X. Man, F. S. Gao. Stratified air conditioning air flow simulation and concentration field analysis of high and large clean plant. HVAC, 34 (8): 94-98, 2004.

7. C. L. Lin, H. Tawhai Merryn, E. A. Hoffman. "Multiscale image-based modeling and simulation of gas flow and particle transport in the human lungs', Wiley Interdisciplinary Reviews Systems Biology \& Medicine, 5(5): 643-655, 2012.

8. E. Vardoulakis, D. Karamanis, A. Fotiadi, et al. "The urban heat island effect in a small Mediterranean city of high summer temperatures and cooling energy demands", Solar Energy, 94(4): 128-144, 2013.

9. Q. Y. Ma, S. X. Zhao, L. Huang, et al. "Numerical Simulation of UFAD Conditioned Space under Summer Part-Load Conditions". Advanced Materials Research, 960-961: 625-630, 2014.

10. X. F. Dong, W. Xiao, B. Zhao. "The simulation and energy saving analysis of CFD simulation and energy saving analysis for tall and clean workshop", HVAC, 42 (11): 58-62, 2012.

11. N. Cai, C. Huang. "A Study of Cooling Load Calculation of Stratified Air Conditioning System for Large Space Based on the Simultaneously Solving Model", Applied Mechanics \& Materials, 672-674: 1755-1761, 2014.

12. J. Taweekun, V. Akvanich. "The Experiment and Simulation of Solid Desiccant Dehumidification for AirConditioning System in a Tropical Humid Climate”, Engineering, 05(1): 146-153, 2013.

13. G. Zhang, J. Xiong, H. Gao, et al. "Hospital Operating Room Clean Air-Conditioning System: Design and Application", Journal of Environment \& Health, 27(9): 814-817, 2010.

14. A. H. Zaji, H. Bonakdari. "Efficient methods for prediction of velocity fields in open channel junctions based on the artifical neural network", Engineering Applications of Computational Fluid Mechanics, 9(1): 220-232, 2015.

15. A. Ali, H. Kalisch. "On the Formulation of Mass, Momentum and Energy Conservation in the KdV Equation", Acta Applicandae Mathematicae, 133(1): 1-19, 2014.

16. A. Krasiński, M. Urban. "The Results of Analysis of Deep Excavation Walls Using Two Different Methods of Calculation", Archives of Civil Engineering, 57(1):59-72, 2011.

17. N. Cui, J. C. Xie, W. Y. Bian, et al. "Study on the Relationship between Indoor Air Quality and Children's Health in Beijing", Applied Mechanics and Materials, 368-370(1): 525-530, 2013.

18. D. Biau. "Laminar-turbulent separatrix in a boundary layer flow", Physics of Fluids, 24(3): 263-268, 2012.

19. F. R. Menter, Y. Egorov. "The Scale-Adaptive Simulation Method for Unsteady Turbulent Flow Predictions. Part 1: Theory and Model Description”, Flow Turbulence \& Combustion, 85(1): 113-138, 2010.

20. Z. Kang, Y. Zhang, H. Fan, et al. "Numerical Simulation of Coughed Droplets in the Air-Conditioning Room", Procedia Engineering, 121:114-121, 2015.

21. C. J. Keylock, G. Constantinescu, R. J. Hardy. "The application of computational fluid dynamics to natural river channels: Eddy resolving versus mean flow approaches”, Geomorphology, 179(2):1-20, 2012. 
22. L. Xia, P. Zhang, R. Z. Wang. "Numerical heat transfer analysis of the packed bed latent heat storage system based on an effective packed bed model", Energy, 35(5):2022-2032, 2010.

23. P. H. Yoon, T. Umeda. Nonlinear turbulence theory and simulation of Buneman instability. Physics of Plasmas, 17(17):112317-112317, 2010.

Received 13.06.2016

Revised 26.09.2016 


\section{LIST OF FIGURES AND TABLES:}

Fig. 1. Schematic diagram of a single-machine system in operating room

Rys. 1. Schemat ideowy układu jednego urządzenia w obszarze operacyjnym

Fig. 2. Schematic diagram of a multi-machine system in operating room

Rys. 2. Schemat ideowy układu wielu urządzeń w obszarze operacyjnym

Fig. 3. The relationship between wind speed of the operating areas and ventilation times in model A

Rys. 3. Zależność między prędkością wiatru w obszarze operacyjnym i czasem wentylacji w modelu A

Fig. 4. The relationship between wind speed of the operating areas and ventilation times in model B

Rys. 4. Zależność między prędkością wiatru w obszarze operacyjnym i czasem wentylacji w modelu B

Fig. 5. The relationship between wind speed of the operating areas of model $\mathrm{A}$ and $\mathrm{B}$ and ventilation times

Rys. 5. Zależność między prędkością wiatru w obszarze operacyjnym modelu A i B oraz czasem wentylacji

Tab. 1. Air supply velocity under different ventilation rates $(\mathrm{m} / \mathrm{s})$

Tab. 1. Prędkość przepływu powietrza przy różnych współczynnikach wentylacyjnych $(\mathrm{m} / \mathrm{s})$

Tab. 2. Turbulence degree $\beta$ of the operation areas under different ventilation times

Tab. 2. Stopień turbulencji $\beta$ w obszarze operacyjnym przy różnych czasach wentylacji 


\section{PLAN I SYMULACJA PROJEKTU KLIMATYZACJI W SZPITALU, NA PODSTAWIE OBLICZENIOWEJ MECHANIKI PLYNÓW}

Slowa kluczowe: technologia obliczeniowej mechaniki płynów; czysta sala operacyjna; symulacja numeryczna; model turbulencji; projekt inżynieryjny

\section{STRESZCZENIE:}

Przedmiotem tego badania była czysta sala operacyjna. Zastosowano technologię czystej klimatyzacji. Obciążenie chłodnicze czystej klimatyzacji w okresie letnim zostało obliczone przy użyciu praktycznej metody obciążenia chłodniczego klimatyzacji oraz oprogramowania służącego do obliczania zużycia energii. Wyniki obliczeń zostały porównane i przeanalizowane. Model rozprowadzania powietrza był symulowany za pomocą Airpak 3.0, a symulowane wyniki zostały przeanalizowane. Ostatecznie uzyskano następujące wnioski.

(1) Opracowano modele fizyczne i matematyczne dla czystych sali operacyjnych. Użyto wstępnego procesora oprogramowania Fluent, w celu opracowania modelu geometrycznego dla obszaru przepływu. Warunki brzegowe, takie jak szybkość wylotu powietrza, ciśnienie na wlocie powietrza oraz ściana sali operacyjnej zostały określone zgodnie z praktyczną sytuacją sali operacyjnej. Domena obliczeniowa sali operacyjnej została rozproszona przy użyciu metody objętości skończonych. Dokonano obliczeń cyfrowych symulacji dla modelu turbulencji RNG K-E. Opracowano kryteria konwergencji obliczeń dla równania ciągłości, równania pędu i równania bilansu energetycznego. Funkcja po przetwarzaniu oprogramowania Fluent została wykorzystana w celu analizy przepływu powietrza na sali operacyjnej, co zostało przedstawione w postaci wizualizacji.

(2) Obszar wlotów powietrza oraz położenie i liczba wylotów powietrza zostały zmienione na podstawie oryginalnego modelu sali operacyjnej, w celu opracowania trzech oddzielnych rodzajów modeli operacyjnych, które zostały ze sobą połączone, lecz jednocześnie się od siebie różniły. Częstotliwość wentylacji (która wzrosła z 15 ACH do 50 ARH), pole prędkości i pole temperatury zostały przetworzone na podstawie obliczenia symulacyjnego. Wyniki symulacji dowiodły, że wraz ze wzrostem częstotliwości wentylacji, prędkość wiatru w sali operacyjnej również wzrastała, lecz temperatura nie uległa znaczącej zmianie. Obszar wylotu powietrza modelu A powiększył się od $2.4 \mathrm{~m} 2$ do $4.68 \mathrm{~m} 2$. Wzrost liczby wlotów powietrza może doprowadzić do zwiększenia obszarów jednokierunkowego przepływu w głównym obszarze przepływu, a także spowodować zwiększenie wirów wewnętrznych i poziomów turbulencji pola prędkości na obszarze operacyjnym. Średnia wartość turbulencji pola prędkości w obszarze operacyjnym modelu A wyniosła 0.11, czyli mniej niż w przypadku modelu B (0.26). Prędkość w modelu A była bardziej oczywista niż w przypadku modelu B. Dlatego też, biorąc pod uwagę wszystkie powyższe czynniki, model A został wybrany jako preferowany schemat dla rozprowadzania strumienia powietrza na sali operacyjnej.

(3) Charakterystyki obciążenia cieplnego wilgotności zostały przeanalizowane, a powszechnie stosowane metody obróbki cieplnej wilgotności i modele działania systemu klimatyzacji zostały podsumowane. Obliczono obciążenie cieplne, objętość świeżego powietrza i całkowitą objętość dopływu powietrza z klimatyzacji w salach operacyjnych. W warunkach projektowych symulacji, zarówno latem i zimą, dokonano porównania punktu rosy i zużycia energii klimatyzacji wyposażonej w główny system wlotu powietrza i wtórny system wlotu powietrza w różnych temperaturach pokojowych, obciążenia oraz różnic temperatur powietrza dostarczanego. Analiza dowiodła, że wraz ze spadkiem temperatury wewnętrznej, różnica między mocą chłodniczą i mocą grzewczą głównego systemu wlotu powietrza może być większa; efekt oszczędności energii wtórnego systemu wlotu powietrza był bardziej oczywisty. Gdy zimny ładunek pozostaje w niezmienionym stanie a przyrost wilgoci wzrasta, amplituda zmiany temperatury punktu rosy wtórnego systemu wlotu powietrza jest wyższa niż w przypadku głównego systemu wlotu powietrza, a wilgotność względna powietrza doprowadzanego jest mniejsza, co okazało się korzystne dla pracy filtra. Fakt wzrostu różnicy temperatury wlotu powietrza i niezmienionej temperatury punktu rosy wtórnego systemu wlotu powietrza jest korzystny dla kontrolowanego działania jednostki klimatyzacji. 